\title{
The analysis of $\mathbf{A} / \mathbf{H}$ premium
}

\author{
Meilin Liu \\ School of Management and Economics, The Chinese University of Hong Kong (Shenzhen), Shenzhen \\ 518172, China \\ chloe_lml@163.com
}

Keywords: A/H premium, dual listing, segmented stock market.

\begin{abstract}
From early 1990s, companies can be dually listed in mainland and Hong Kong markets, however, the puzzle is that prices of A-shares are always higher than that of H-shares, this difference is known as $\mathrm{A} / \mathrm{H}$ premium, described by HSAHP index. This paper will analyze this phenomenon from two perspectives, which are macro perspective - liquidity differences, different trading systems, industry differences and exchange rate, and micro perspective - including information asymmetry, investors’ risk preferences and differential demand elasticities.
\end{abstract}

\section{Introduction}

This paper analyzes the stock price disparity of A- and $\mathrm{H}$ - shares in Chinese mainland and Hong Kong markets, which is a special and puzzling case in the world.

In early 1990s, China conducted the policy of reform and opening. Because of this policy, especially the opening of Shanghai and Shenzhen's security markets, Chinese equity market experienced a rapid development. From that time, Chinese companies can be dually listed in both mainland China and Hong Kong. However, considered protecting the stability of domestic stock market from capital flows, China set limits on access by foreign investors, separating and restricting shares into different categories for domestic Chinese resident investors and foreign investors. Ashares are domestic-only shares which are listed in either Shanghai or Shenzhen, and H-shares foreign-only shares that are listed in Hong Kong (John Fernald \& John H. Rogers, 2002).

For mainland resident investors, they are not allowed to purchase $\mathrm{H}$-shares, while foreigners cannot legally purchase A-shares which are domestic-only. Other than who can own them and transactions are conducted in different currencies, they are legally identical, holders can receive the same voting rights and dividends.

Traditionally, A-shares are traded in Shanghai or Shenzhen, while H-shares are traded in Hong Kong, but after introducing Shanghai-Hong Kong Stock Connect to the two markets in 2014, investors could purchase A- or H- shares in either Shanghai or Hong Kong.

Many studies have been done to examine the primary cause of this price disparity. Based on past studied, this paper first describes some basic properties of $\mathrm{A} / \mathrm{H}$ premium and then analyses various possible causations from both macro and micro aspects.

\section{Background}

The puzzle is that prices of A-shares and H-shares of the company both listed in mainland stock market and Hong Kong market are primarily different. For most of the time, A-shares priced higher than $\mathrm{H}$ - shares, this is what people usually called $\mathrm{A} / \mathrm{H}$ premium. That means in China's segmented stock market, domestic residents pay more than foreigners. However, this is not a usual case in the world. China is special - mainland stock market is still segmented from the global market. In most countries with investment restrictions, contrasts with China, foreigners generally pay a premium for an identical asset. For example, Bailey, Chung and Kung (1999) carried out a research of market features of domestic and foreign shares in eleven countries, and they discovered that except China, other countries' foreign shares cost more than domestic shares. In addition, from the data of Finland 
market stock market during 1984 to 1985, Hietala and Pekka (1989) found out that foreign investors paid higher average prices for identical assets. Additionally, China's stock market is different from most emerging market in many aspects. For example, China has its unique transition path way, which is from central panning to a reliance on market forces.

Since the first state owned company Tsingtao Brewery listed in Hong Kong main board in 1993, the difference of average prices for foreign-only shares relative to prices for corresponding domestic shares in two market varied over time. During late 1997 to the early 1998, foreigners paid less than about one quarter the price paid by Chinese resident.

By the end of May in 2017, among 91 AH shares, up to 25 stocks' A/H premium exceed 200\%, the highest one's A-share price is 4 times of its H-shares price. There are 87 stocks in total show A/H premium, and only 4 stocks' A-shares are discounted related to H-shares. Furthermore, these AH share companies share some common features. In addition, most of these AH companies are big enterprises, especially state-owned enterprises. And they account for around $20 \%$ of total market value in A-share market.

There can be two main features, the first one is $\mathrm{A} / \mathrm{H}$ premium fluctuates greatly over time; the other is cross-sectional difference of $\mathrm{A} / \mathrm{H}$ premium is large. The Hang Seng China $\mathrm{AH}$ Premium Index ("HSAHP") captures the average price difference of A-shares over $\mathrm{H}$ shares for the largest and most liquid Chinese companies with both A-share and H-share listings ("AH Companies"). HSAHP consist of 60 constituent stocks from 9 different industries. Figure1 shows in detail, among the 60 constituent stocks, there are twenty stocks come from finance field, accounts for 67.09 percent, which is the largest part of the index. Energy, materials and consumer goods show equal amount of stocks in index - six stocks from each industry and weight 8.81 percentage, 3.08 percentage and 3.86 percentage respectively. As for industrial and properties \& construction industry, there are 8 and 7 constituent stocks for each and weight 4.95 percentage and 8.23 percentage respectively.

However, no stocks from telecommunications and conglomerates is included in HSAHP index. Overall, most of the financial constituent stocks' level of $\mathrm{A} / \mathrm{H}$ premium is lower than other industries and stays around 100 percent. Meanwhile the highest $\mathrm{A} / \mathrm{H}$ premium of all constituent stocks is higher than 200 percent, whose industrial classification is energy. While the lowest one is lower than 90 percent.

Since HSAHP index is a simple and easy-to-follow indicator of the absolute premium or discount of A-shares over H-shares of AH companies. For its performance then, from figure 2 HSAHP index weekly data, it can be easily seen that index fluctuate greatly overtime, mainly around the interval between 80 and 160. Before 2010, A/H premium was more volatile and higher, peak at over 180 in 2008. From 2008 to 2010, it showed a tendency of declining with fluctuation. Then between 2010 and 2014, A/H premium was relatively stable and fluctuate mainly around 100 . However, after Shanghai-Hong Kong Stock Connect was introduced, from the end of the year 2014 to the beginning of 2015, HSAHP suddenly rose to almost 140 and varied in the interval between 120 to 140 in the next two years. The gap between the price of A-shares and H-shares should have been narrowed due to Shanghai-Hong Kong Stock Connect, the fact is just the reverse though. ShanghaiHong Kong Stock Connect strengthens the mobility of capital and reduces information asymmetric, which lead to financial stock $\mathrm{A} / \mathrm{H}$ premium become stable, but intensify non-financial stocks premium. 


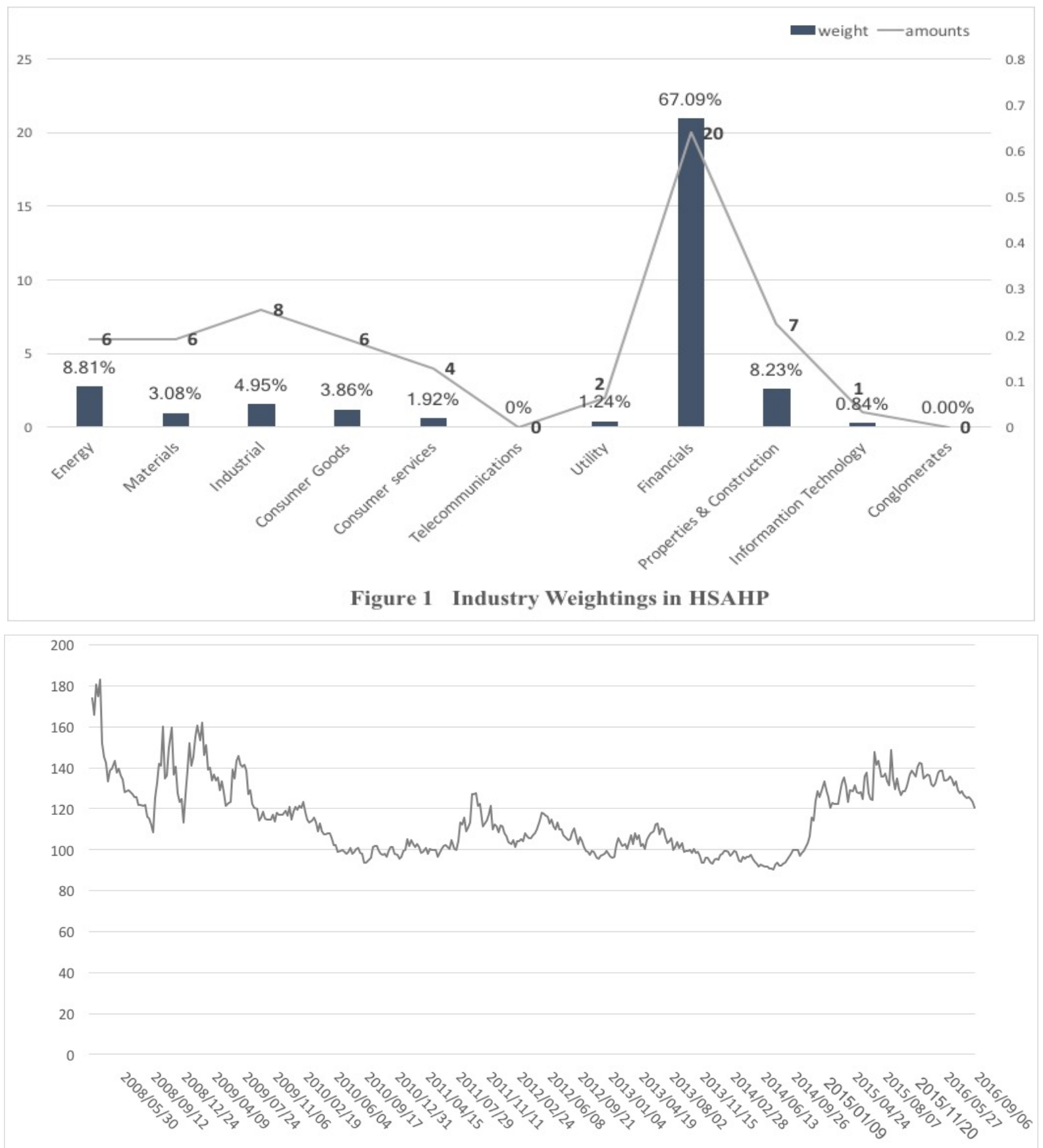

Figure 2 HSAHP Index weekly data

\section{Macro factors}

\subsection{Liquidity differences}

First, according to liquidity hypothesis, the different levels of liquidity in different markets will affect the price level in different stock markets. Since the liquidity preference theory suggests that investors prefer highly liquid holdings such as cash, and liquid investments can be easier to sell quickly for full value. So, investors demand a higher premium or interest rate on the investments with lower liquidity. That's why investors in the market with lower liquidity level, where there is higher trading costs, requires lower stock price or higher return than in the high liquidity markets.

In terms of A-shares and H-shares, John Fernald and John H. Rogers (2002) suggested that about 4 percentage-points difference exists between their returns, and they contribute this difference to less investment alternatives in mainland China than in Hong Kong market. Despite of deposits, Ashares is one of the major investment methods for Mainland investors, investors in mainland prefer 
short-term speculative buck, and they trade more frequently, so Chinese mainland stock market is more liquid. As for Hong Kong market, H-share is just one choice among various investment opportunities, and foreign investors need to pay additional trading fees, so they require higher returns and lower prices to compensate their cost due to different liquidity in these two markets.

\subsection{Different trading system}

Since A-shares and H-shares are traded in different markets, they are subject to different rules and requirements. For example, from the perspective of limits to arbitrage, short- selling of Ashares in mainland is not permitted, but part of H-shares can be short sold, Kalok Chan*, Hung Wan Kot and Zhishu Yang (2010) investigate this short constraint of H-share stocks on the A/H premium. They find that when the market falls, H-shares are priced more fairly than A-shares, because both optimists and pessimists can participant in the market, while pessimists are more likely to quit the market in mainland due to different short-selling situation. Then some companies in mainland market are overvalued. For those short $\mathrm{H}$-shares, their prices decrease more when the economy goes down. Short constraints take an active role in explaining the change of $\mathrm{A} / \mathrm{H}$ premiums when market falls.

Other market rules such like " $\mathrm{t}+1$ " in mainland market, investors who buy stocks today are forbidden to sell the stocks in the same day, they should sell them in the next trading day. That is different from Hong Kong market, where investors are free to buy and sell one stock in the same trading day. Wang Huixin (2016) argues that such trading rule can help Hong Kong to improve the market trading volume and short-term trading which requires that investors' better risk management ability. But short-term arbitrage is limited in mainland market due to this strict rule.

In addition, there is a $10 \%$ price limit in mainland market and for ST and $*$ ST stocks the price limit is $5 \%$. As for PT stocks the rise limit is $5 \%$ and there is no limit on the range of price drop. This price limit in mainland limits the fluctuation range of stock price and blocks some short-term arbitrage which is to the disadvantage of discovering the market prices.

\subsection{Industry difference}

Industry attributes also contribute to price variance of stocks in these two market. Stocks in different industry are at different premium level. Wang Huixin (2016) gives one obvious example in 2008 financial crisis, stocks from financial field in mainland China market were discounted related to $\mathrm{H}$ shares in Hong Kong market, while A/H premium still existed in other industries. Comparing mainland and Hong Kong economic situations, in 2008 mainland was still at the stage of developing heavy industry, focused on manufacturing industry, and financial sector was developing relatively slower. However, Hong Kong as one of world trade center, whose finance development is ahead of mainland, and economy grew more mature at that time. Furthermore, features of Hong Kong financial industry, such like abundant financial tools, little restrictions on capital flow, no foreign exchange control, are different from financial industry in mainland, and they attracted large amount of international financial institutions and investors, and trading market scale is among top of the world.

Another example is that HSBC Holdings is an old Hong Kong financial listing institution, when mainland financial companies are listed in Hong Kong, investors will price it with reference to HSBC Holdings. However, for mainland manufacturing companies, there is little proper pricing reference for investors in Hong Kong market, which makes it difficult to give those companies reasonable pricing. Finally, these factors lead Hong Kong market to give premium to financial companies.

\subsection{Interest rate}

In terms of currency, H-shares are traded in Hong Kong market using HKD while A-shares are traded in mainland market using RMB, then exchange rate will also contribute to this price disparity. John Fernald and John H. Rogers (2002) states that for foreign investors, they are faced with exchange-rate risk, because an expected depreciation raises foreigners' yuan-denominated required return so they may require a higher rate of return to compensate such risk. In addition, expectation 
of exchange rate also influences $\mathrm{A} / \mathrm{H}$ premium. As for the relationship of expected exchange rate and $\mathrm{A} / \mathrm{H}$ premium, earlier study Arquette et al (2007) concluded that expected exchange rate accounts for $40 \%$ variance of the share discount, which in some way explained the different price across regions. Once the expectation of investors from mainland and Hong Kong changes, they will react to the change of exchange rate expectation. Using both empirical and theoretical method, Tian Tan (2016) pointed out that the higher relative interest will lead to a relatively lower discount rate in Hong Kong, thus supporting a higher valuation of Hong Kong stock price than Shanghai.

\section{Micro factors}

\subsection{Asymmetric information}

Theoretically, in a perfect market, investors have equal ability to access to relative information, and equity market is highly transparent. However, the fact is not the case, and many studies show that asymmetric information is a significant factor that cause the price disparity.

Chinese equity market as an emerging market, foreign investors have difficulty accessing information about Chinese enterprises. In reality, asymmetric information may be a more severe issue in China, because of problems such as not legally codified investor protection rights, share manipulation and widespread insider trading (Chan, Menkveld and Yang (2008)) It means that domestic investors who are trading A-shares have the edge on foreign investors who are trading $\mathrm{H}$ shares regarding to information, and that is one important reason for $\mathrm{H}$-shares are discounted related to A-shares.

In addition, due to language, accounting standards difference, foreign investors lacking information about Chinese economic situation and details about those firms comparing to mainland investors (Chakravarty, Sarkar and Wu (1998)). Such kinds of information barriers lead to foreign investors stay in a disadvantage position. With more information, domestic investors tend to gain more returns, so foreign investors need compensation for information asymmetry which results in A/H premium.

\subsection{Risk preference}

Investors' different risk preferences will also have an influence on their required risk premium and further causes price difference. Since investors in mainland and Hong Kong equity market have different levels of expected return and rationality, their risk aversion degrees are different.

Eun and Janakiramanan (1986) established an equilibrium asset pricing model and it indicates that in a two-countries situation, with the presence of international investment barriers which means that foreign investors are limited to own shares of domestic firms, the price difference occurs in those two markets. Based on their model, differential risk hypothesis arose, and it suggests that foreign and domestic investors have different risk preference, and the foreign equity price discount is related to the ratio of aggregate risk aversion of the two markets (Lee, 2009).

In mainland equity market, investors, as mentioned before, prefer short-term speculative behaviors and tend to hold a positive view on future returns. Ma (1996) states that since the mainland stock markets are speculative, then speculative investors in Chinese market can bear higher levels of risk than can foreign investors who have higher level of risk aversion. Furthermore, mainland investors focus more on fluctuations of stock price and can easily be affected by sheepFlock Effect. While in Hong Kong market, investors are more rational, and prefer low risk investments, which represents they are more risk averse and requires relatively high premium to compensate for risk. The different risk aversion levels lead to differential required risk premium of investors, and finally results in the price disparity of A-shares and H-shares.

\subsection{Differential demand elasticities}

Since A-shares and $\mathrm{H}$-shares are traded in different markets with diverse market conditions, investors in mainland and Hong Kong markets have different demand elasticities, which further affect stock prices in these two markets. 
Chan and Kwok (2005) point out that because of lacking overseas diversification investment opportunities due to capital control and the interest rate on RMB deposits is relatively low and unattractive, the demand for stocks by Chinese retail investors are huge. In addition, the liquidity of Chinese treasury securities is weak and government and state-owned enterprises control substantial shares of listed firms. So, mainland investors' demand elasticities of A-shares are low. However, in Hong Kong market, B-shares and red-chips are good substitutes for H-shares, and investors can access to diversified overseas investments. These lead to their demand elasticities for domestic shares are relatively high

Stulz and Wasserfallen (1995) also indicate that there are differential demands for domestic shares between domestic and foreign investors, and those different investors groups have different demand elasticities. Based on that, the firms may want to discriminate between investors to maximize firm value, so they set restrictions on investors' investments. And their findings suggest that demand curves of both domestic and foreign investors are downward-sloping, instead of perfectly elastic demand curves. In mainland market, the firms are faced with investors whose demand elasticities are relatively low, while in Hong Kong market shares suppliers are faced with high demand elasticities investors. So, mainland investors having low demands elasticities tend to pay higher prices than Hong Kong investors, which causes A/H premium.

\section{Conclusion}

In Chinese segmented market, $\mathrm{A} / \mathrm{H}$ premium is a unique phenomenon that domestic investors pay much higher price than foreign investors for an identical asset. This paper is meant to examine the possible causations of $\mathrm{A} / \mathrm{H}$ premium. From historical data, it can be easily seen that $\mathrm{A} / \mathrm{H}$ premium is highly volatile and the differences between various industries are large. Conbining with its historical performance, and based on the previous findings about what cause $\mathrm{A} / \mathrm{H}$ premium, this paper analyses seven possible explanations - from macro perspectives, it includes liquidity differences, different trading systems, industry differences and exchange rate; from micro perspective, it includes information asymmetry, investors' risk preferences and differential demand elasticities. Foreign investors need lower prices or higher returns to compensate for their possible loss due to the disadvantage position compared to domestic investors in China, furthermore, domestic investors are willing to pay higher prices due to lacking investment alternatives and many other reasons. It is hard to say which one factor ultimately contribute to this phenomenon. Different markets environment together with different groups of investors and many other various factors in these two different markets can lead to $\mathrm{A} / \mathrm{H}$ premium.

A/H premium still remains a puzzle, and worth further exploration.

\section{References}

[1] Arquette, Gregory C., William O. Brown, and Richard CK Burdekin. "US ADR and Hong Kong H-share discounts of Shanghai-listed firms." Journal of Banking \& Finance 32.9 (2008): 1916-1927.

[2] Bailey, Warren, Y. Peter Chung, and Jun-Koo Kang. "Foreign ownership restrictions and equity price premiums: what drives the demand for cross-border investments?" Journal of financial and quantitative analysis 34.04 (1999): 489-511.

[3] Chakravarty, Sugato, Asani Sarkar, and Lifan Wu. "Information asymmetry, market segmentation and the pricing of cross-listed shares: theory and evidence from Chinese A and B shares." Journal of International Financial Markets, Institutions and Money 8.3 (1998): 325-356.

[4] Chan, Kalok, Albert J. Menkveld, and Zhishu Yang. "Information asymmetry and asset prices: Evidence from the China foreign share discount." The Journal of Finance 63.1 (2008): 159-196.

[5] Chan, Kalok, Hung Wan Kot, and Zhishu Yang. "Effects of short-sale constraints on stock prices and trading activity: Evidence from Hong Kong and mainland China." (2010).

[6] Chan, Kalok, and Johnny KH Kwok. "Market segmentation and share price premium evidence 
from Chinese stock markets." Journal of Emerging Market Finance 4.1 (2005): 43-61.

[7] Eun, Cheol S., and Sundaram Janakiramanan. "A model of international asset pricing with a constraint on the foreign equity ownership." The Journal of Finance 41.4 (1986): 897-914.

[8] Fernald, John, and John H. Rogers. "Puzzles in the Chinese stock market." Review of Economics and Statistics 84.3 (2002): 416-432.

[9] Hietala, Pekka T. "Asset pricing in partially segmented markets: Evidence from the Finnish market." The Journal of Finance 44.3 (1989): 697-718.

[10] Huixin Wang. Research on influence factors of AH premium [D]. Nanjing University of Science and Technology, 2015.

[11] Lee, Hing - Wah. "The Price Premium of China A - Shares over Hong Kong H - Shares: A Further Visit of the Liquidity Hypothesis." Asia - Pacific Journal of Financial Studies 38.5 (2009): 657-694.

[12] Ma, Xianghai. "Capital controls, market segmentation and stock prices: Evidence from the Chinese stock market." Pacific-Basin Finance Journal 4.2-3 (1996): 219-239.

[13] Stulz, René M., and Walter Wasserfallen. "Foreign equity investment restrictions, capital flight, and shareholder wealth maximization: Theory and evidence." Review of financial studies 8.4 (1995): 1019-1057.

[14] Tan, Tian. Currency Expectation and AH Share Disparity of China and Hong Kong. Diss. Boston College. College of Arts and Sciences, 2013. 